Man and Nature

L'homme et la nature

\title{
New Trends in the Form and Function of the Dénouement: German Empfindsamkeit and Sturm und Drang
}

\section{Anna Wittmann}

Volume 3, 1984

URI : https://id.erudit.org/iderudit/1011828ar

DOI : https://doi.org/10.7202/1011828ar

Aller au sommaire du numéro

Éditeur(s)

Canadian Society for Eighteenth-Century Studies / Société canadienne d'étude du dix-huitième siècle

ISSN

0824-3298 (imprimé)

1927-8810 (numérique)

Découvrir la revue

Citer cet article

Wittmann, A. (1984). New Trends in the Form and Function of the

Dénouement: German Empfindsamkeit and Sturm und Drang. Man and Nature /

L'homme et la nature, 3, 101-111. https://doi.org/10.7202/1011828ar

Copyright (c) Canadian Society for Eighteenth-Century Studies / Société canadienne d'étude du dix-huitième siècle, 1984
Ce document est protégé par la loi sur le droit d'auteur. L'utilisation des services d'Érudit (y compris la reproduction) est assujettie à sa politique d'utilisation que vous pouvez consulter en ligne.

https://apropos.erudit.org/fr/usagers/politique-dutilisation/ 


\section{New Trends in the Form and Function of the Dénouement: German Empfindsamkeit and Sturm und Drang}

The Romantic Era in Europe has long been regarded as an age of literary change - an age in which formal conventions are undone, generic distinctions transformed, loosened, or blended, and in which the original genius of the artist creates, through the unleashing of his subjectivity, a constantly shifting mosaic of the dense interrelationships between subject and object, the self and the external world. ${ }^{1}$ The programmatic statements of early Romantic theorists reinforce this rupture with literary conventions. Friedrich Schlegel, for instance, repeatedly maintains that the poetics of the past are both restrictive and outworn and that the contemporary age must move toward a fuller and more organic conception of art:

Die meisten Vorstellungsarten vom poetischen Weltsystem sind noch so roh und kindisch wie die ältern vom astronomischen vor Kopernikus. Die gewöhnlichen Einteilungen der Poesie sind nur totes Fachwerk für einen beschränkten Horizont. ${ }^{2}$

The polemical insistence of the Romantics on literary innovation must not obscure, however, the currents of change which were already in motion in the course of the eighteenth century. Two elements of the interrelationship of literary texts must be kept in mind: first, that individual works form an interlinking chain, whereby new additions to the system 
must be seen within the context of the whole in their dynamic interaction with other texts; and second, that literary changes are seldom arbitrary or isolated. ${ }^{3}$ Conventions must exist before they may be broken, and literary innovation itself is frequently composed of a gradual series of changes. Transitional developments must not be overlooked, since shifts in aesthetic outlook and practice interlink with transformations in ethos and social, political and historical circumstances.

One such seemingly abrupt but, in reality, gradually evolving change may be found in the form and function of the dramatic dénouement. Although clear-cut generic distinctions between tragedy and comedy are, in the wake of the eighteenth century, no longer applicable, the present study limits itself to the 'serious' genres of drama rather than to the predominantly comic ones. My findings from an ongoing study of closure reinforce the thesis that, to varying degrees, the form and function of the dénouement of the 'serious' Romantic drama marks a radical departure from traditional closure practices in preceding dramas from Antiquity to the late eighteenth century.

Traditionally, the dénouement of the serious drama preceding Romanticism is closed, in that the fate of the major characters is determined and no major questions or problems are left unresolved. Conventionally, the drama moves from the peripety of the climax to the somewhat static equilibrium of the ending. In short, the complications of the action have been unravelled, and the closing passage of the play marks, as Aristotle states, a falling action. ${ }^{4}$ The emotions of pity and fear reach a peak and lead to release in the cathartic action of the dénouement. ${ }^{5}$ Not only are the survivors of the tragedy depicted in the drama led to a new harmony and equilibrium, but also the spectators share in the new vision of peace. As Theophil Spoerri summarizes, the spectator

... spürt, daß es eine Macht gibt, die seinem Leben einen neuen Sinn geben kann ... Für einen Augenblick fühlt er sich im Frieden mit der Welt. Es ist die eigentümliche Ruhe, die unerwartet mitten im tragischen Spiel den kämpfenden Helden überfällt und sich geheimnisvoll dem Zuschauer mitteilt. ${ }^{\circ}$

Many examples may serve to illustrate traditional closure practice. Hamlet, for instance, although in many ways rupturing the classical unities, employs a typically harmonious and stable outcome. As in Shakespeare's other historical tragedies, the final speakers in Hamlet are secondary characters who have remained more or less intact throughout the course of tragic events and who represent the forces of stability and continuity in the existing social order. Their role in the dénouement is twofold: first, to eulogise the life and death of the hero; and second, to 
embody the concepts of survival and restored equilibrium. Hamlet's successor Fortinbras efficiently and decisively sets about the reestablishment of a stable monarchy, as the play is brought down from the heights of pity and fear reached in the preceding scenes.

Robert Heilman comments on the significance of the conventional dénouement:

This ending, of course, is a convention, a formalized management of proprieties that had authority in their day. Yet the convention itself is significant: it could not exist, we may conjecture, without faith in a transmittable order of values, and belief in continuity; the ending is a symbol of something earned in the tragic action, in contrast with the total sense of loss in dramas of despair and disaster. The dramatist's own sense of continuity may be more or less profound, and he may build the convention firmly into the plot or employ it casually, like a verbal tag. ${ }^{7}$

With the advent of Romanticism, however, the traditional forms and functions of dramatic closure are radically altered. Not only are the classical unities of time, place and action definitively shattered in Romantic theory and practice, but also the unresolved, abrupt, or turbulent dénouement is employed. Tension and emotion continue, often unmitigated, to the very end of the play; strands of unresolved conflict may remain, questions and problems may be left unanswered, and the action of the drama may come to a merely artificial halt, propelled forward, in the minds of the audience or reader, to an unknown outcome beyond the formal ending. Sudden surprise developments may transform the ending into a coup de théâtre, and final events frequently may not evolve rationally and inevitably from the body of the plot. Man may remain at odds with society and unreconciled with the limitations of human existence. The concept of a heile Welt (a benevolent world order) frequently disappears as world history and, in particular, the exceptional individual are caught up in a cycle of an ongoing universal tragedy. The dénouement may, moreover, lose its unity of focus if a wide variety of emotions and responses is depicted, and one level of perception is kaleidoscopically substituted for another. At the same time, striking visual effects may predominate over verbal elements.

These radical changes in the form and function of the dénouement culminate in Romanticism. ${ }^{8}$ Nevertheless, the roots of dramatic change must be traced in the earlier literary period. Already in the eighteenth century, currents of change in the use of the dénouement are evident, along with a progressive approximation to the dramatic practice of the Romantics. 
In what has been referred to as 'the most important play to appear in Germany before Lessing's Miß Sara Sampson,'9 the dénouement is still modelled upon largely conventional lines. At the close of Gottsched's Der sterbende Cato (1730), Cato lies dying of a self-inflicted wound when revelation of his tragic flaw comes to him. He has, he realizes, carried his love of freedom too far, so that it has been transformed into obduracy. His uncompromising struggle with Caesar has served to undermine the stability of the Roman state. Nevertheless, the ending of the play does not flounder in despair. At the moment of Cato's death, Providence acts to reward him for his previous virtue as news is brought of the triumphant resolution of his conflict with Caesar. Cato's final words reaffirm his trust in Providence, and suggest that, through rightful conduct, man will eventually achieve his aims of a stable and enlightened existence. Addressing the gods, Cato says,

Ihr kennt ja

unser Herz, und prüfet die Gedanken!

Der Beste kann ja leicht vom Tugendpfade wanken.

Doch ihr seyd voller Huld ... ${ }^{10}$

What emerges from this dénouement is a traditionally harmonious vision, cloaked in Enlightenment optimism, which triumphs over tragic despair. As Heitner observes,

Man in this tragedy is viewed, not as a lone being achieving a sad greatness in his defiance of the hostile universe, but as an honestly striving, somewhat handicapped pupil ... forgiven and rewarded in the life to come. ... In the neat and orderly universe of this play, the same general rule of reason and virtue is held up to every action so that all regrettable occurrences can be explained as the result of failure to observe the rule ... . ${ }^{\prime 11}$

In spite of the death of the hero, the forces of stability and continuity in the existing social order are predominant. Equilibrium once more prevails and serves to bring down the play from the heights of pity and fear of the preceding scenes. In Aristotelian terms, catharsis is complete.

Only twenty-five years later, however, with Lessing's Miß Sara Sampson (1755), and even more with Emilia Galotti (1772), a shift away from traditional conventions, along with a corresponding change in ethos, is evident. At this point, it is necessary to look back upon the changes in dramatic theory and practice which take place in a European as well as a German context. In the course of the eighteenth century, the Aristotelian-based genre of 'tragedy' is loosened, and the situations and problems of its protagonists so far changed that, in effect, the generic 
designation is expanded and modified. The tragedy loses its preoccupation with socially exalted individuals and is transformed into the tragédie bourgeoise of Diderot or into the German bürgerliches Trauerspiel. From the French comédie larmoyante (literally, the 'tearful comedy'), the serious drama takes up a sentimental tone, aiming to engage the spectator or reader in tears of compassion. Both the sentimental mode and the bourgeois setting of tragedy find their forerunners in England with Richardson's novel Pamela (1740), a portrait of a supremely virtuous and tearful bourgeois heroine, and with Lillo's London Merchant (1731), a domestic tragedy depicting the moral and physical demise of a merchant's apprentice. Similarly, Lessing's bourgeois tragedy, Miß Sara Sampson, moves to the intimate milieu of the bourgeois family in a relatively humble social setting and imparts to its characters and events an emotional immediacy hitherto unknown in German tragedy.

In Lessing's bourgeois tragedy, traditional moral values are profoundly questioned. As Benno von Wiese comments, 'das Menschliche und das Moralische fallen nicht einfach zusammen, sondern durchdringen sich spannungsvoll.'12 The plot is simple: a young girl falls in love and elopes with her profligate lover, who refuses to marry her. Sara's father, Sir William, although initially stern, pursues her, forgives her and her lover's transgressions, and begs them to return to his home. Both father and daughter admit guilt: Sara, for her lack of modesty and moral firmness, and Sir William, for his initial moral rigidity and condemnation. Lessing thus suggests that human fault stemming from innocence must be forgiven and that mercy should be present in all moral judgements.

In spite of Sara's basic virtue and her father's final generosity, their mistakes have dire consequences. The outcome does not entirely reinforce the idea of a heile Welt. Sara is reconciled to her father only to die of a slow poison administered by her lover's ex-mistress. The dénouement thus reveals the powerlessness of virtue and mercy in the face of misfortune and evil. Obliquely, the outcome suggests that the social order of the world is such that deceit and raw power triumph over goodness. The final atmosphere is, however, one of reconciliation as, in a final gesture of generosity and forgiveness, Sir William determines to adopt the illegitimate daughter of Sara's murderess and seducer. His closing words reflect composure and a determination to continue a constructive life:

Laß mich nicht länger, Waitwell, bei diesem tötenden Anblicke verweilen. Ein Grab soll beide umschließen. Komm, schleunige Anstalt zu machen, und dann la $ß$ uns auf Arabellen denken. Sie sei, wer sie sei: sie ist ein Vermächtnis meiner Tochter. ${ }^{13}$ 
Greater complexity infuses the dénouement of Emilia Galotti and, far more than in Miß Sara Sampson, the foundations of the heile Welt are shaken. Edoardo Galotti, the model of bourgeois Rechtschaffen, slays his daughter Emilia - an action which she herself desires - to save her from forcible seduction at the hands of the licentious Prinz von Gunstalla. Private morality and the corrupt power of the state have thus come into a conflict which can be resolved honourably only through the selfsacrifice of virtue. Galotti's desperate upholding of virtue ironically transforms him into a murderer in the eyes of the state; at the same time, his earthly judge, the corrupt prince, is a tyrant who heeds no moral or social laws. The dénouement offers no immediate solution to this dichotomy between individual morality and a corrupt society. At the same time, Galotti is convinced of final justice at the hands of God: 'Ich gehe und liefere mich selbst in das Gefängnis. Ich gehe und erwarte Sie als Richter. - Und dann dort - erwarte ich Sie vor dem Richter unser aller!'14 This justice is, however, only partial, removed from the actual world. No solution is offered for the mockery of justice and the abuse of power upon earth. The equilibrium of the dénouement is therefore already beginning to become unbalanced in eighteenth-century German drama.

Analogous dénouements exist in many dramas of the Sturm und Drang period in the later eighteenth century. Behind the adolescent furor of Sturm und Drang, the melodramatic posturings of its rebellious heroes, its moral relativism, and the runaway eloquence of its language lies much, in fact, which links it with Empfindsamkeit. The family is still much in the forefront, although it has now been infused with internal conflict; social criticism, rendered sharper by the iconoclastic tendencies of the Sturm und Drang hero, continues, and has now expanded to take on a historical dimension; and sentimentalism has led to bombastic language and unbounded bursts of emotion. At the same time, the social and political tensions depicted in these dramas still do not lead to a nihilistic rejection of society or moral standards. Equilibrium still partially operates in the dénouement.

The Empfindsamkeit and Sturm und Drang dramas included in this study share one common element in their closure: all do indeed represent a resolution of the action. Following Aristotle's prescription, they represent a complete action, and, unlike many Romantic dramas, do not leave the audience or reader in suspense as to the eventual outcome. With the possible exception of Wagner's Kindsmörderin (1777), the German eighteenth century drama is complete with the dénouement. In Die Kindsmörderin, the execution of the seduced heroine who has slain her illegitimate child is imminent, while her repentant lover, v. Gröningseck, 
is left in paroxysms of his 'Reue nach der Tat. ${ }^{15}$ Nevertheless, the apparent desertion of Evchen by her seducer is revealed as a gigantic mistake resulting from the perfidy of a deceitful friend, and some hope remains for a royal pardon as v. Gröningseck determines to rush to Versailles to put his case before the king:

Und Ihnen nebst Ihrer ganzen kriminalischen Unfühlbarkeit zum Trotz, mein Herr! will ich mich heut noch auf den Weg nach Versailles machen, bei der gesetzgebenden Macht selbst Gnade für sie auszuwürken, oder - ${ }^{16}$

The dénouements of Empfindsamkeit and Sturm und Drang dramas fall into two major groups and one sub-group. First, there are those of reconciliation which reveal a partial resolution of tensions, exemplified by Miß Sara Sampson, Goethe's Götz von Berlichingen (1773), Leisewitz's Julius von Tarent (1776), and Schiller's Die Räuber (1781). A subdivision of this group is formed by dramas which employ the distancing devices of irony in the dénouement. Into this group, the 'reconciliatory-ironic,' fit Lessing's Emilia Galotti, Lenz's Die Soldaten (1779), and Schiller's Die Verschwörung des Fiesco zu Genua (1783). The second major division I have chosen to call the dénouements of 'sustained tension.' On the one hand, their closing scenes follow naturally and fairly predictably from the body of the plot, and serve to complete the action, leaving few major problems unresolved; on the other, they end explosively, with little of the falling-off of tension or emotion revealed in the first major group. Representative of this group are Gerstenberg's Ugolino (1768), Klinger's Zwillinge, and Wagner's Reue nach der Tat (1775). An even more transitional dénouement with strong elements of the frequent open-endedness of Romantic drama is, as observed above, that of Wagner's Kindsmörderin.

The outcome of Miß Sara Sampson, our first example from the 'reconciliation' endings, employs, as we have pointed out, a 'falling action,' as the resigned composure and determination of Sir William to continue with the matters of living lead to a relaxation of emotion and renewed stability. To a smaller degree, Goethe's Götz von Berlichingen concludes on a note of elegiac calm. Reconciliation takes the form of resignation to a corrupt age and a desperate hope for social reform in the future. In the present age, however, harmony is found only beyond the earth: Nur droben, droben bei dir, ${ }^{17}$ i.e., with God in the afterlife. On another level, Karl Moor in Die Räuber, an angry young man who has countered the corruption of society with lawlessness and violence, performs an about-face in the dénouement of the drama. After the loss of his entire family, including his father and his lover, he comes to the tragic realiza- 
tion that to attempt to change the world order by repaying evil with evil merely propagates destruction. ${ }^{18}$ Only by giving himself up to justice, he determines, can he achieve forgiveness for his sins. Through his imminent death, ironically, he reenters the human society he has previously spurned. The final reconciliation is, however, only partial. The antagonism of the exceptional individual and a restrictive social milieu is only artificially resolved through the hero's repentance, and the final harmony is purchased at the price of total defeat and self-destruction.

While notes of triumph are heard in the reconciliatory group, the reconciliatory-ironic dénouement contains little of this positive element. In spite of the falling-off of action and emotion, irony injects a discordant note. Schiller's Verschwörung des Fiesco zu Genua, for instance, ends with the defeat of the republican cause in Genoa, spurred on by the superbia of Fiesco, the erstwhile revolutionary leader. Only one action, the removal of the new tyrant and the restoration of the previous but more benevolent tyrant, can save the state from disintegration. The understated words of Verrina, the self-appointed murderer of Fiesco, ironically emphasize the failure of the revolution: 'Ich geh zum Andreas. ${ }^{\prime 19}$ Revolution has thus accomplished a complete circle which leaves political conditions finally unchanged, and the reinstatement of equilibrium takes the form of compromise. One other innovative technique is employed in the stage directions: 'Alle bleiben in starren Gruppen stehn. Der Vorhang fällt.' With the freezing of stage movement in a tableau of dumbfounded spectators, Schiller precipitates a prominent device of the later Romantics. Not only words but also the suspension of symbolic and significant action brings the dénouement to a new prominence. Similarly, the closure of Lenz's Die Soldaten ironically emphasizes the circularity and lack of resolution in human society. The dénouement only restores harmony insofar as father and daughter are reconciled and reunited; in a type of double dénouement, the closing discussion between the pseudo-enlightened Gräfin and Obrister on the problems of soldier morality throws ironic light upon the ongoing corruption and blindness of society.

The second major group of dénouements, those of 'sustained tension,' offer little falling-off of emotion and hence do not exemplify traditional catharsis. One of the earliest Sturm und Drang dramas, Gerstenberg's Ugolino, concludes upon a note of renewed harmony which is, however, far removed from the subdued calm of the traditional dénouement. To the accompaniment of a crescendo of background music, the hero determines with courage to face inevitable death by starvation. His final words are emotionally charged and endow a climactic effect upon the dénouement: 'Ich hebe mein Auge zu Gott auf. Meine zerißne Seele ist 
geheilt ... Und dann seid mir gepriesen, die ihr diesen Leib der Verwesung hinwarft! Ganz nahe bin ich am Ziel. ${ }^{20}$ A more open-ended dénouement is found in Klinger's Zwillinge. Although the action is, in one sense, resolved through the father's punishment of his younger son's murder of the elder brother, the play ends in an explosion of despair as the father cries, 'Rächen will ich Vater Guelfos Sohn! erretten von der Schande Guelfos Sohn! leben im Jammer verwaist $-^{\prime 21}$ and stabs his son. Through the slaying of his own younger son to avenge the murder of the elder, he has, in effect, rendered himself childless. This self-destructive act of justice is an admission by Guelfo of his failure to accomplish the ideals of love and family loyalty which have formed the basis of his life. As his final words intimate, his future life will be devoid of harmony, a time of prolonged suffering.

In conclusion, the dénouements here outlined are significant, both in themselves and in their literary-historical position as indicators of a major change in dramatic theory and practice. They throw light upon the Weltanschauung of the later eighteenth century and upon the innovative nature of an age breaking away, philosophically and artistically, from traditional forms and attitudes. While Der sterbende Cato, our example of a traditional outcome, concludes smugly with a belief in the best of all possible worlds and the perfectibility of man through virtue and reason, the dramas of Empfindsamkeit and Sturm und Drang reveal a gradual loss of belief in the foundations of a heile Welt. As precursors of Romantic dramatic practice, they already point to the open-endedness, lack of resolution, ambivalence, and melodramatic explosiveness of Romantic endings.

The first type of dénouement here outlined - the 'reconciliatory,' with its subgroup, the 'reconciliatory-ironic,' is transformed into three basic types in Romanticism. First, the 'transcendent' dénouement of the Romantics resolves existential dilemmas by rejecting immediate reality in favour of a higher, transcending vision. The inverse of this type, of which the 'reconciliatory-ironic' is the precursor, is found in the 'nihilistic' dénouement of Romantic dramas, where no resolution is found, and the protagonists continue to be the prey of destructive forces. Yet another group in Romanticism, the 'circular' dénouement, is closely allied to the previous one. It contains no positive resolution for, although the fate of the protagonists is outwardly determined, humanity continues to play the part of a tragic (or even tragi-comic) hero in an ongoing world tragedy. Finally, the second group of Empfindsamkeit and Sturm und Drang dramas, those of 'sustained tension,' transforms itself into two types in Romanticism: the 'climactic' dénouement and the 'symbolic tableau.' The climactic dénouement replaces the traditional falling action 
of the conclusion with a rising one, and frequently leaves questions unanswered and the action only partially resolved. A coup de théâtre, or surprise twist in events, is often incorporated. The 'symbolic tableau' subordinates verbal to visual elements. The final events, unresolved tensions, and even the future course of action are immobilized and held in a concluding 'stage picture' or tableau, upon which the curtain falls.

German drama, it must be remembered, does not move exclusively from Empfindsamkeit and Sturm und Drang to Romanticism. The 'angry young man' movement of the Sturm und Drang was short-lived. Its two most prominent survivors, Goethe and Schiller, shifted in their later years to a Classical ideal, and reveal, in their later dramas, little of the open-endedness of their Sturm and Drang work. Nevertheless, the innovative trends introduced in the latter half of the eighteenth century are further developed and expanded by the new generation of Romantic dramatists at the opening of the nineteenth century. The radical changes accomplished in the form and function of the dénouement of serious drama become a characteristic and distinguishing feature of European Romantic drama. Already in the eighteenth century, however, the dénouement emerges as a significant indicator of a new Weltanschauung and serves as a vantage point from which we can examine the emergence of a new ethos and aesthetic practice. Most important, the study of changes in the form and function of the dénouement illustrates the dynamic linkage of innovative trends in literary history.

\author{
ANNA WITTMANN \\ University of Alberta
}

Notes

1 See H.H.H. Remak, 'West European Romanticism: Definition and Scope,' in Comparative Literature: Method and Perspective, ed. N. Stallknecht and Horst Frey (Carbondale: Southern Illinois University Press, 1971), pp. 275-311.

2 Werke in zwei Bänden, ed. Wolfgang Hecht (Berlin and Weimar: Aufbau Verlag, 1980), I, 'Fragmente,' No. 434, p. 255.

3 See T. Todorov, The Fantastic. A Structural Approach to a Literary Genre, trans. Richard Howard (Cleveland: Case Western Reserve University Press, 1973), p. 2; also Maria Corti, An Introduction to Literary Semiotics, trans. D. Mandelbaum, (Bloomington: Indiana University Press, 1978), p. 2: 'Literature is not the sum of its texts but a kind of totality linked and linking, and in movement.' 
4 Aristotle, Poetics, trans. and ed. Gerald F. Else (Ann Arbor: University of Michigan Press, 1967), p. 36.

5 Ibid., p. 36.

6 Theophil Spoerri, 'Das Problem des Tragischen. Aus der Perspektive des französischen Dramas gesehen,' in Tragik und Tragödie, ed. V. Sander (Darmstadt: Wissenschaftliche Buchgesellschaft, 1971), p. 78.

7 Tragedy and Melodrama: Versions of Experience. (Seattle: University of Washington Press, 1968), pp. 160-61.

8 These findings are based on my dissertation project, 'The Structure and Function of the Dénouement in German, French and English Romantic Drama,' currently in progress. An abbreviated version is due to appear in the International Comparative Literature Association's forthcoming History of Romantic Drama in European Languages, ed. G. Gillespie.

9 Robert Heitner, German Tragedy in the Age of Enlightenment (Berkeley: University of California Press, 1963), p. 26; see also Jürgen Jacobs, 'Daß klassizistische Drama der Frühaufklärung' in Handbuch des deutschen Dramas, ed. Walter Hinck (Düsseldorf: Bagel, 1980), p. 63.

10 Johann Christoph Gottsched, Ausgewählte Werke, ed. Joachim Birke (Berlin: De Gruyter 1970), II, p. 113.

11 Heitner, p. 31.

12 Benno von Wiese, Die deutsche Tragödie von Lessing bis Hebbel (Hamburg: Hoffmann und Campe, 1961), p. 33.

13 Gotthold Ephraim Lessing, Gesammelte Werke, ed. Wolfgang Stammler (München: Hanser, 1959), I, p. 398.

14 Ibid., I, p. 624.

15 The prominence of the theme of remorse in Wagner's work is revealed by the title of an earlier drama, Die Reue nach der Tat (1775).

16 Heinrich Leopold Wagner, Die Kindsmörderin in Sturm und Drang: Eine Auswahl, ed. Erich Loewenthal and Lambert Schneider, 3rd ed. (Heidelberg: Schneider, 1972), II, p. 605.

17 Johann Wolfgang von Goethe, Götz von Berlichingen in his Werke, ed. Wolfgang Kayser, IV (Hamburg, 1953), p. 175.

18 Friedrich Schiller, Sämtliche Werke, ed. Gerhard Fricke et al. (München: Hanser, 1962), I, p. 617.

19 Ibid., p. 751.

20 Heinrich Wilhelm von Gerstenberg, Ugolino in Sturm und Drang: Eine Auswahl, I, p. 61.

21 Friedrich Maximilian Klinger, Die Zwillinge in Sturm und Drang: Eine Auswahl, II, p. 123. 